\title{
A Diachronic Study of the Authorial Identity in Tourism Research Articles
}

\section{(Studi Diakronis terhadap Identitas Kepenulisan dalam Artikel Ilmiah Pariwisata)}

\author{
Gusti Ayu Praminatih \\ Institut Pariwisata dan Bisnis Internasional \\ Jalan Kecak No. 12, Gatot Subroto Timur, Denpasar 80239 \\ Tel.: +62(361)426699 \\ Surel.: gusti.praminatih@ipb-intl.ac.id
}

\begin{abstract}
Abstrak
Penelitian ini bertujuan untuk mengkaji tipe, fungsi, dan korelasi dari kata ganti orang pertama pada artikel ilmiah pariwisata menggunaan metode linguistik korpus diakronik. Penggunaan kata ganti orang pertama (saya, kami) dalam penulisan artikel ilmiah masih menjadi problematik bagi penulis pemula maupun penulis berpengalaman. Akan tetapi, beberapa penelitian menunjukkan penggunaan kata ganti orang pertama semakin sering digunakan di penulisan artikel ilmiah untuk menunjukkan identitas kepenulisan. Adapun artikel ilmiah pariwisata yang digunakan sebagai data dalam penelitian ini diakses dan diunduh dari lima jurnal akses terbuka yang dipublikasikan oleh Elsevier. Terdapat 80 artikel ilmiah pariwisata yang dipilih dari tahun 2015 hingga 2020 yang dibangun menjadi lima korpora. Perangkat lunak AntConc digunakan untuk mencari kata ganti orang pertama dari korpora tersebut. Penelitian ini menunjukkan bahwa penulis artikel ilmiah pariwisata menggunakan kata ganti orang pertama saya dan kami dalam enam tipe identitas kepenulisan dari yang kurang otoritatif hingga yang sangat otoritatif selama lima tahun terakhir. Selain itu, identitas kepenulisan yang dibentuk memiliki tiga fungsi utama bagi penulis artikel ilmiah pariwisata, bidang ilmu pariwisata, serta pembaca artikel ilmiah pariwisata. Perhitungan statistik menunjukkan korelasi yaitu 0.87 yang menunjukkan terjadi peningkatan penggunaan kata ganti orang pertama dari tahun ke tahun.
\end{abstract}

Kata kunci: artikel ilmiah pariwisata, identitas kepenulisan, kata ganti orang pertama, linguistik korpus diakronik

\begin{abstract}
This study aims to investigate types, functions, and correlation of the first-person pronouns (FPPs) in tourism research articles (RAs). The use of FPPs (I, we) in tourism Ras was increasingly used to indicate the authorial identity. To pursue the aim of this study, qualitative method was used together with diachronic corpus linguistics approach. Data used in this study then were collected from five open access journals published by Elsevier. In total, there were 80 tourism RAs selected from the year 2015 to 2020 classified into five corpora. AntConc software then was applied to retrieve the FPPs from the corpora. The results of this study showed that the FPPs, I and we, were
\end{abstract}


constructed as six types of authorial identity ranging from the least to the strongest authoritative identity in the past five years. The authorial identity constructed was also known to have three main functions, namely for the authors of tourism RAs, tourism as an academic discipline, and the readers of tourism RAs. Besides, this study also revealed that the use of the FPPs increased in each year with the correlation value of 0.87 .

Keywords: authorial identity, diachronic corpus linguistics, first-person pronouns, tourism research articles

\section{INTRODUCTION}

Writing or not writing the first-person pronouns (FPPs) such as $I$ and we as self-reference in writing research articles (RAs) was often perplexing for inexperience and even advanced authors (Hyland 2001, 208). Given the formal, rigid, and impersonal nature of academic writing (Hyland \& Jiang 2017, 41), it would be problematic for the author if they attempted to use the FPPs. Moreover, the research conducted by Biber \& Finegan (1989), Chang \& Swales (2014), Hyland $\&$ Jiang (2017) revealed that the researchers had perpetual concern on the occurrence of the FPPs as one of the informal elements in writing RAs. Their research suggested that the FPPs were one of the common informal features along with other colloquial aspects such as inexact anaphoric pronouns, the second-person pronouns, splitting the infinitives, starting the sentence with conjunctions and conjunctive adverbs, ending the sentence with prepositions, using listing expressions, run-on sentences, sentence fragments, using contractions, direct question, and exclamation. Consequently, the authors who employed the FPPs as self-reference in RAs were risked of informal tones that could lead to subjectivity, vagueness, and openness to the readers.

Although the FPPs were unwelcomed in RAs, the situation could be completely different among various academic writing cultures. For example, Myers (2001, 64) quoted in Hewings (2001) asserted that the authors in humanities and social science in British were obliged to write personal arguments in their academic papers, otherwise, they would get low marks. Therefore, the use of FPPs was inevitable. Furthermore, Paltridge \& Starfield $(2007,13)$ argued that FPPs played an essential role as the key to construct an authorial identity. Nevertheless, it would be difficult for the second-language authors that were often required to avoid it. Wallwork $(2011,115-16)$ explained that in writing academic papers, FPP we was legitimised in the research method section to established the authors' contribution to the research. Nevertheless, the authors could not use the FPP for merely showing the thinking processes. Besides, Swales \& Feak $(2012,12)$ asserted that the FPPs were widely employed in single and co-authored RAs to construct authorial identity especially in a hard science such as engineering. Nevertheless, some authors were remaining reluctant to use it. Subsequently, the FPPs could be employed by the authors of RAs for at least three purposes such as to give personal arguments, to mention the steps conducted in the RAs, and to construct authorial identity.

Tang and John $(1999,27-29)$ divided the authorial identity in RAs into six types that classified from the least authoritative to the most authoritative identity. The six types of authorial identity were identified as the representative, the guide, the architect, the recounter, the opinion holder, and the originator. The representative was the least authoritative identity. The authors acted as a member of a larger community that shared a similar background of knowledge. The guide was a stronger identity than the representative. The authors became the informers to their readers. Above the guide, there was the architect. The authors mentioned that they were the ones who conducted the steps in RAs. The recounter was stronger than the architect. The authors retold how the steps had been accomplished in RAs. Then, there was the opinion holder. The author 
mentioned their perspectives regarding existing information or knowledge. The last and the most authoritative identity in the hierarchy was the originator. The author claimed as the inventor of knowledge and idea.

The extensive amount of research on the use of the FFPs as authorial identity had been conducted in the previous years. Hyland $(2001,214)$ researched the occurrence of the FPPs in hard science

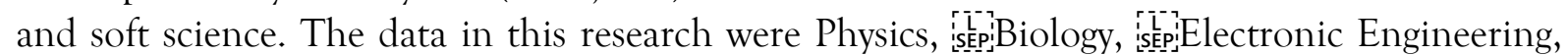
Mechanical Engineering RAs to represent hard science and Marketing, Philosophy, Applied Linguistics, Sociology RAs to represent soft science. The research found that the FPPs were the authors' indication of self-confidence, knowledge, self-importance, representation of their disciplinary, authorisations and trustworthiness, and academic closeness with their readers. McCrostie (2008, 104-106) identified the occurrence of the FPPs in argumentative writing essays written by Japanese first-year university students who majoring English. The research revealed that they were overly used as an interpersonal device. Nevertheless, the statistics were dropped in the following semester as the students gained more experience in academic writing. Zareva (2013, 78-81) discovered there were five out of six types of authorial identity employed by the students who took the master's degree of Applied Linguistics with TESOL concentration. The types of authorial identity were the guide, the architect, the recounter, the opinion holder, and the originator. It was also explained that the FPPs appeared both in spoken and written academic genres. The types of authorial identity were consciously constructed in writing and less consciously in spoken.

Leedham \& Fernandez-Parra $(2017,71-73)$ obtained the data from a merit corpus called The British Academic Written English (BAWE). The research had signified that the FPP we was employed excessively rather than the FPP I among the Chinese and Greek undergraduate and master students majoring in Engineering in the UK. Unlikely, the UK students, with the same degree and major, were preferred to employ more of the FPP I. The FPP we served as the representative and the guide and the FPP I served more as the reflector. The functions of these types of authorial identity were preparing for professional practices and developing research skills. Taylor \& Goodall $(2019,141)$ investigated the FPP I. The research found that the FPP I served as numerous rhetorical functions in Business students' academic writing in various genres. The rhetorical functions of the FPP I were recognising support and gratitude, stating one's self and actions, recounting purposes and decisions, stating the aims of writing, explaining the method, explaining the argument, proposing suggestions and recommendations, and quotations. Cheng (2020, 9-10) collected the data from bachelor theses, master theses, doctoral dissertations, and conference abstract papers within the Language field of study. The finding showed the different frequency of occurrence the FPP I among the Chinese authors' academic writing. The Chinese authors employed more of the FPP I when they were using English. Unlikely, they avoided using it when they were using Chinese. The Chinese authors would prefer to show modesty and politeness when writing in their native language.

The aforementioned research suggested that analysis of the FPPs to construct authorial identity in tourism RAs received very little concern from the researchers. Tourism RAs were rarely employed as the data to represent soft science, let alone collected it as the main data or a corpus. Tourism had been acknowledged as a field of science for many years. There were many tourism RAs published by leading international journals. Moreover, tourism had a wide range of topics and interests such as sustainable tourism, cultural tourism, the marketing of tourism to name a few. Consequently, current research focused on analysing the FPPs in the tourism field of study diachronically. The research attempted to investigate three research problems. First, investigate 
the types of authorial identity in tourism RAs. Second, investigate the functions of authorial identity in tourism RAs. Third, since it was diachronic research, it was essential to investigate whether or not the use of the FPPs was generally increasing or decreasing in tourism RAs. Subsequently, this study contributed new insights on linguistics aspects especially the FPPs in tourism RAs for future researchers, tourism research authors, and also research advisors.

\section{METHOD}

The mixed-method was employed in current research. Dörnyei $(2007,163)$ explained a mixed method as the collection and analysis of both quantitative and qualitative data in a single research. Creswell $(2014,117)$ asserted that mixed method must involve both numeric and text data and analysis. The quantitative part of this research was the data derived from a computerised corpus where the corpus tool calculated the concordance and frequency of results automatically. Moreover, there were also normalisation and correlation calculations in this research. The results that were retrieved from the corpus tool, normalisation number, and correlation required further interpretation. Thus, the qualitative part was required when explaining the types and functions of the types of authorial identity that occurred in tourism RAs. Accordingly, this research could only be conducted correctly by combining both quantitative and qualitative approaches.

The data collection began by obtaining tourism RAs from five open access journals (OA) published by Elsevier from the year 2015 to 2020. Elsevier was a prominent publisher with above 250,000 journal articles per year (Vázquez 2015). Thus, Elsevier was selected because it had a substantial amount of journal articles that would guarantee the availability and variety of data. The five OAs that employed in this research were Annals of Tourism Research, Tourism Management, Tourism Management Perspectives, Journal of Destination Marketing $\mathcal{E}$ Management, and Journal of Outdoor Recreation and Tourism. There were 80 tourism RAs downloaded from the aforementioned OAs. They were divided into five corpora based on their respective year. Then, tourism RAs were converted into plain text file format using AntFileConverter software. This process was required because AntConc, the main corpus software in this research, processed the inputted data in plain text file format.

The FPP I and the FPP we were retrieved respectively from AntConc concordance where the results were displayed in the AntConc software. However, instead of relied fully on the automatic raw results from the software, careful selections of the relevant FPPs were necessary to achieve accurate results. There were two types of irrelevant results that were eliminated. The elimination was conducted after reading the context of the FPPs in the AntConc concordance. They were the FPPs that appeared from the authors' research acknowledgment section and the FPPs that retrieved from the data employed by the authors such as travel stories, blog stories, travel diary, and interview transcription. The total numbers of FPPs from this selection was normalised. Normalisation was highly required because the total tokens were different in each corpus. These results in the form numbers were interpreted further to explain about the types and functions of the authorial identity. The following process was calculating the correlation between tourism RAs and the normalised number.

\section{RESULTS AND DISCUSSION}

There were three subsections in this research. The first subsection discussed the types of authorial identity in tourism RAs. The second subsection discussed the functions of authorial identity in tourism RAs. The third discussed the correlation between the years and normalisation numbers. 


\section{The Types of Authorial Identity in Tourism RAs}

The FPPs distributions in the corpora were accessed separately. AntConc software allowed its users to retrieve only one word in each session. Subsequently, the FPP I was searched in the concordance and then followed by the FPP we. The tabulation of distributions of the FPPs was presented in Table 1.

Table 1. The Normalised Number of The FPPs in Tourism Ras (Per 100,000 Words)

\begin{tabular}{ccccccc}
\hline Year & 2015 & 2016 & 2017 & 2018 & 2019 & 2020 \\
\hline $\begin{array}{c}\text { Normalised } \\
\text { Number }\end{array}$ & 41.67 & 76.78 & 99.06 & 170.23 & 124.93 & 160.31 \\
\hline
\end{tabular}

The normalisation of the FPPs distributions should be further interpreted. In the corpus of 2015, there were four types of authorial identity constructed by the authors of tourism RAs. They were the architect, the recounter, the opinion holder, and the originator. There was zero distribution of the FPP I. In this year, only the FPP we were employed. The types of the authorial identity of the FPP we were presented respectively as examples $1-4$.

(1) We examine the stories in travel blogs with the aim [...] (Annals of Tourism Research)

(2) We did follow-up interviews and participant observations. (Tourism Management)

(3) we believe the present study is one of strong candidates [...] (Tourism Management)

(4) We found fewer references to positive emotions in the stories [...] (Annals of Tourism Research) In example (1), the FPP we was the architect by mentioning the examination they did on the stories in travel blogs. In example (2), the FPP we was the recounter by recounting the follow-up interviews and participants' observations that had been conducted. In example (3), the FPP we was the opinion holder by stating personal belief of their study. In example (4), the FPP we was the originator by conveying the research finding.

In the corpus of 2016, there were five types of authorial identity constructed by the authors of tourism RAs. They were the guide, the architect, the recounter, the opinion holder, and the originator. Like the corpus of 2015, there was zero distribution of the FPP I in the corpus of 2016. Similarly, only the FPP we were employed. The types of the authorial identity of the FPP we were presented respectively as examples 5-9.

(5) we see around us can be considered as a potential [...] (Tourism Management)

(6) we propose a new conceptualisation of destinations [...] (Tourism Management)

(7) we adopted the FCM-FD algorithm as a method able to [...] (Tourism Management)

(8) we look at the use of CHAID as a segmentation [...] (Journal Destination Eु Marketing Management)

(9) We make a novel contribution to the literature by integrating [...] (Tourism Management) In example (5), the FPP we was the guide by acting as the informer to the readers. In example (6), the FPP we was the architect by mentioning what they propose in their research. In example (7), the FPP we was the recounter by recounting FCM-FD algorithm that they adopted. In example (8), the FPP we was the opinion holder by stating their understanding toward ethnicity as a sociohistorical construction. In example (9), the FPP we was the originator by claiming that they made a novel contribution to the literature.

In the corpus of 2017, there were five types of authorial identity constructed by the authors of tourism RAs. They were the architect, the recounter, the opinion holder, and the originator. Unlike 2015 and 2016 corpora, both the FPPs I and we were employed. The type of authorial identity $I$ was presented as example 10 . 
(10) I call it differentiation, since it separates a paradox into [...] (Tourism Management) In example (10), the FPP I was the opinion holder by stating the author's a point of view.

Furthermore, the types of the authorial identity of the FPP we were presented respectively as examples 11-14.

(11) we attempt to predict travellers' attitudes toward a tourist attraction [...] (Tourism Management)

(12) we have presented a method for analysing seasonality in the [...] (Journal of Outdoor Recreation and Tourism)

(13) We argue that authenticity can therefore be constituted through people's relationship [...] (Annals of Tourism Research)

(14) We could also declare them unresolvable and move on. (Tourism Management)

In example (11), the FPP we was the architect by mentioning they were attempting to predict the travellers' attitude. In example (12), the FPP we was the recounter by recounting that they had been presented a method for analysing seasonality. In example (13), the FPP we was the opinion holder by stating their argument on authenticity. In example (14), the FPP we was the originator by conveying a declaration in their research.

In the corpus of 2018, there were five types of authorial identity constructed by the authors of tourism RAs. They were the representative, the architect, the recounter, the opinion holder, and the originator. Likewise the corpus of 2017, both the FPPs I and we were employed. Nevertheless, the FPP I were more varied than the previous corpus. The types of the authorial identity of the FPP I were presented respectively as examples 15-17.

(15) I read a recently submitted evaluation form. (Tourism Management Perspectives)

(16) I organised the collected data in a way that reflects [...] (Tourism Management Perspectives)

(17) I do not suggest that guides should hold back from [...] (Tourism Management Perspectives)

In example [15], the FPP I was the architect by mentioning the reading of the submitted evaluation form. In example [16], the FPP I was the recounter by recounting that they had been organized the collected data. In example [17], the FPP I as the opinion holder was conducted by conveying judgement.

Additionally, the types of the authorial identity of the FPP we were presented respectively as examples 18-22.

(18) We know from previous research that social structural variables are (Journal of Outdoor Recreation and Tourism)

(19) we show results for two models with alternative specifications of [...] (Journal of Outdoor Recreation and Tourism)

(20) we tested the following hypotheses in our study. (Annals of Tourism Research)

(21) We will thus argue that only the qualitative approach could [...] (Tourism Management)

(22) We produced a novel, complete and consistent dataset describing the [...] (Tourism Management)

In example (18), the FPP we as the representative by pointing out they and the reader shared common knowledge on the previous research. In example (19), the FPP we was the architect by mentioning that they showed the results for two models. In example (20), the FPP we was the recounter by recounting they had been tested the hypotheses of their study. In example (21), the FPP we was the opinion holder by stating their argument on the qualitative approach. In example (22), the FPP we was the originator by conveying that they produced a novel in their research. 
In the corpus of 2019, there were four types of authorial identity constructed by the authors of tourism RAs. They were the architect, the recounter, the opinion holder, and the originator. Similar to 2018 and 2019 corpora, the FPPs I and we were employed. The types of the authorial identity of the FPP I were presented respectively as examples 23-24.

(23) I investigate how Norwegian Caucasian midlife single women think and [...] (Annals of Tourism Research)

(24) I coded the transcripts several times, seeking to make comparisons [...] (Annals of Tourism Research)

In example [23], the FPP I was the architect by mentioning that they investigated single female Norwegian Caucasian midlife tourists. In example [24], the FPP I as the recounter by recounting they had been coded the transcripts of their research.

Then, the types of the authorial identity of the FPP we were presented respectively as examples 25-28.

(25) we conceptualise accessibility in tourism, because previously the focus has [...] (Annals of Tourism Research)

(26) we used the National Survey of Household Income and Expenditures (Annals of Tourism Research)

(27) we are certain that the findings obtained offer a clear [...] (Annals of Tourism Research)

(28) we found that the expected tourist participation rate and tour (Tourism Management)

In example (25), the FPP we was the architect by mentioning conceptualisation of the accessibility in tourism. In example (26), the FPP we was the recounter by recounting they had been employed the National Survey of Household Income and Expenditures in their research. In example (27), the FPP we was the opinion holder by stating their certainty of the finding. In example (28), the FPP we was originator by conveying the research finding.

In the corpus of 2020, there were four types of authorial identity constructed by the authors of tourism RAs. They were the architect, the recounter, the opinion holder, and the originator. Similar to 2015 and 2016 corpora, there was zero distribution of the FPP I in 2020. Similarly, only the FPP we were employed. The types of the authorial identity of the FPP we were presented respectively as examples 29-32.

(29) We present the first application of unique mobile phone network data to evaluate (Tourism Management)

(30) We started our analysis for a period of two years [...] (Tourism Management Perspectives)

(31) we argue that online research on experience value should recognize [...] (Tourism Management Perspectives)

(32) we found that halal-tourism-related tweets about non-Muslim countries outnumber those [...] (Tourism Management Perspectives)

In example [29], the FPP we was the architect by mentioning that they presented unique mobile phone network data. In example (30), the FPP we was the recounter by recounting they had been started their analysis for a period of two years. In example (31), the FPP we was the opinion holder by stating their argument on online research on experience value. In example (32), the FPP we was the opinion holder by conveying the finding of their research.

\section{The Functions of Authorial Identity in Tourism RAs}

Myers (2001, 64 in Hewings 2001) asserted that it was an obligation for the British students majoring humanities and social science to writer personal argument the British students' otherwise it would impact their marks. The authors of tourism RAs did not have the obligation 
to get high marks. Therefore, the function of the FPPs here was to show the authors' trustworthiness of their knowledge. The authors of RAs focused on their papers to be accepted by the journal editors and also the readers. Thus, to be trustworthy was required. Besides, Paltridge \& Starfield $(2007,13)$ argued that FPPs was the key to construct authorial identity, however, the second-language authors might felt difficulty to do it because they were often required to avoid it. The author of tourism RAs were advanced writers. They were mostly university lecturers, researchers, or PhD students although many of them were English as Second Language (ESL) and English as Foreign Language (EFL) countries. For native English speakers, writing in academic papers also required years to practice. The authors' writing experiences made them capable to construct the identity. Thus, the function here was to show the writers' experience and capability.

Wallwork $(2011,115-16)$ explained FPP was legitimised in the research method but the authors could not use it to show the thinking processes. The authors of tourism RAs employed the FPPs for both activities. Thus, the function was to show the contributions such as the establishment of the method as well as the finding and the novelty of the research. Besides, the function was to show self-importance by mentioning the thinking process, personal belief, giving the point of view, and stating agreement and disagreement. Furthermore, Swales \& Feak $(2012,12)$ asserted that the FPPs were mostly employed in hard science. On the other hand, Hyland $(2001,214)$ research employed data from hard science and soft science; nevertheless, tourism was not included. Tourism belonged to humanities science. It signified the use of the FPPs was not limited only in hard science. Thus, the function here was to show the importance of the authors' discipline.

McCrostie (2008, 104-106) identified that Japanese first-year university students employed the FPPs as an interpersonal device. The authors of tourism RAs also employed the FPPs as a social device to show openness to the readers. Zareva $(2013,78-81)$ discovered that the FPPs were constructed as the authorial identity consciously in the writing activity and less consciously in the spoken activity. Tourism RAs was in the form of writing; therefore, the types of authorial identity were constructed consciously. Hence, the function was to show the authors' awareness of their constructed identity. Besides, Leedham \& Fernandez-Parra (2017, 71-73), Taylor \& Goodall $(2019,141)$, and Cheng $(2020,9-10)$ analysed the FPPs and the relation to social and rhetorical functions. Their research suggested that the FPPs were influenced by the authors' social culture. Tourism RAs in this research were mostly co-authored. Thus, they employed the FPP we. Nevertheless, single-authored RAs were also employing the FPP we. Thus, the function was to show self-effacement.

\section{The Correlation Calculation}

The following process was calculating process of the correlation between the year of tourism RAs and the normalised number. The tabulation of correlation was presented in Table 2.

Table 2. The Tabulation of Correlation Calculation

\begin{tabular}{ccccccc}
\hline Year & 2015 & 2016 & 2017 & 2018 & 2019 & 2020 \\
\hline $\begin{array}{c}\text { Normalised } \\
\text { Numbers }\end{array}$ & 41.67 & 76.78 & 99.06 & 170.23 & 124.93 & 160.31 \\
\hline Correlation & \multicolumn{7}{c}{0.87} \\
\hline
\end{tabular}


The correlation result was 0.87 . It indicated there was a strong positive correlation between the year and the normalised numbers of Tourism RAs. This strong positive correlation showed that the use of FPPs was increased in each year.

\section{CONCLUSION}

The authors of tourism RAs legitimised the use of FPPs. In this research, the findings indicated that the authors of tourism RAs authors employed the FPPs I and we to construct six types of authorial identity. There were three types of authorial identity constructed by the FPP I. They were $I$ as the architect, $I$ as the recounter, and $I$ the opinion holder. Meanwhile, there were six types of authorial identity constructed by the FPP we. They were we as the representative, we as the guide, we as the architect, we as the recounter, we as the opinion holder, and we as the originator. These constructed types of authorial identity had at least functions that related to the authors, the discipline, and the readers. For the authors of tourism RAs, the functions of the authorial identity were to show the authors' trustworthiness of their knowledge, the writers' experience and capability, the contributions to the research, self-importance, awareness, and selfeffacement. For the tourism discipline, the function of the authorial identity was to show the importance of the authors' discipline. For the readers, the function of the authorial identity was to show the openness to the readers. The correlation result was 0.87. It indicated there was a strong positive correlation between the year and the normalised numbers of Tourism RAs. This strong positive correlation showed the use of FPPs was increased in each year.

\section{REFERENCES}

Anthony, Laurent. 2019a. AntConc (version 3.5.8). Tokyo: Waseda University. https://www.laurenceanthony.net/software/antconc/.

- 2019b. AntFileConverter (version 1.2.1). Tokyo: Waseda University. https://www.laurenceanthony.net/software/antfileconverter/.

Biber, Douglas, \& Edward Finegan. 1989. "Drift and the Evolution of English Style: A History of Three Genres.” Language, 65 (3): 487-517. DOI: 10.2307/415220.

Chang, Yu-Ying, \& John M. Swales. 2014. "Informal Elements in English Academic Writing: Threats or Opportunities for Advanced Non-Native Speakers?" In Writing: Texts, Processes and Practices, edited by Christopher N. Candlin and Ken Hyland. New York: Routledge.

Cheng, Rong. 2020. "Single Author Self-Reference: Identity Construction and Pragmatic Competence." Journal of English for Academic Purposes, 45:1-14. DOI: 10.1016/j.jeap.2020.100856.

Creswell, John W. 2014. Research Design: Qualitative, Quantitative, and Mixed Methods Approaches, Fourth Edition. Thousand Oaks: Sage Publications, Inc.

Dörnyei, Zoltan. 2007. Research Methods in Applied Linguistics. Oxford: Oxford University Press.

Hyland, Ken. 2001. "Humble Servants of the Discipline? Self-Mention in Research Articles." English for Specific Purposes, 20:207-26.

Hyland, Ken, \& Feng (Kevin) Jiang. 2017. "Is Academic Writing Becoming More Informal?" English for Specific Purposes, 45:40-51. DOI: 10.1016/j.esp.2016.09.001. 
Leedham, Maria, \& Maria Fernandez-Parra. 2017. "Recounting and Reflecting: The Use of First Person Pronouns in Chinese, Greek and British Students' Assignments in Engineering.” Journal of English for Academic Purposes, 26:66-77. DOI: 10.1016/j.jeap.2017.02.001.

McCrostie, James. 2008. "Writer Visibility in EFL Learner Academic Writing: A Corpus-Based Study." ICAME Journal, 32:97-114.

Myers, Greg. 2001. “'In My Opinion': The Place of Personal Views in Undergraduate Essays.” In Academic Writing in Context: Implications and Applications, edited by Martin Hewings. Birmingham: The University of Birmingham.

Paltridge, Brian, \& Sue Starfield. 2007. Thesis and Dissertation Writing in a Second Language: A Handbook for Supervisors. London: Routledge.

Swales, John M. \& Christine B. Feak. 2012. Academic Writing for Graduate Students: Essential Skills and Tasks, 3rd Edition. Michigan: University of Michigan Press/ELT.

Tang, Ramona, and Suganthi John. 1999. “The 'I' in Identity: Exploring Writer Identity in Student Academic Writing through the First Person Pronoun.” English for Specific Purposes, 18:23-39.

Taylor, Helen, \& John Goodall. 2019. "A Preliminary Investigation into the Rhetorical Function of 'I' in Different Genres of Successful Business Student Academic Writing." Journal of English for Academic Purposes, 38:135-145. DOI: 10.1016/j.jeap.2019.01.009.

Vázquez, Lucía Muñoz. 2015. "Curious of the Benefits of Publishing with Elsevier?" 2015.https://www.elsevier.com/authors-update/story/tutorials-and-resources/ curious-ofthe-benefits-of-publishing-with-elsevier.

Wallwork, Adrian. 2011. English for Writing Research Papers. New York: Springer.

Zareva, Alla. 2013. "Self-Mention and the Projection of Multiple Identity Roles in TESOL Graduate Student Presentations: The Influence of the Written Academic Genres.” English for Specific Purposes, 32:72-83. DOI: 10.1016/j.esp.2012.11.001. 